\title{
Analysis of published research in IP Indian Journal of Library Science and Information Technology: A Bibliometric Study during 2016-2020
}

\author{
Subhajit Panda* \\ Assistant Librarian, Chandigarh University, Mohali, Punjab, India \\ *Corresponding Author: Subhajit Panda \\ Email: suvapanda007@gmail.com
}

\begin{abstract}
Bibliometrics is the discipline where quantitative methods were employed to probe the scientific communication process by measuring and analyzing various aspects of written documents. It helps to monitor the growth of literature and patterns of research. The present paper is based on the analysis of IP Indian Journal of Library Science and Information Technology (IJLSIT) with the help of bibliometrics parameters during the period 2016 to 2020 . Among the several bibliometric parameters, the study utilizes mainly the number of articles per volume or year, authorship pattern, collaborative pattern, top-most authors, state-, designation-\& affiliation-wise contribution, reference per article count, cited resources type, research trends and research interests. The research data of this study collected manually, analysed with the help of an MS Excel spreadsheet and distinguished according to different types of bibliometric elements. The findings of the study suggested that in IJLSIT, the maximum number of articles published in the year 2019 (25.74\%), 53.47\% (54) articles contributed by a single author, and the overall collaboration rate is 0.47 . Furthermore, $90 \%$ (91) of articles contributed by Indian authors and Hemantha Kumar G.H. is the most productive author. Maharastra (18.81\%) being the most contributed Indian state, Benue State University \& Rayalaseema University (4.95\%) being the most contributed institutions and College Librarians are the most designated contributors (20.79\%). The study further revealed that 0-5 pages are the most common length, 6-10 references are the most common references used per article, and periodicals are the most commonly cited reference types. The area "Digital Library" is nurtured most among researchers, whereas, the year 2018, vol. 3, issue 1 consists of the maximum views number (18.01\%) and the year 2020, vol. 5, issue 1 has the most number of downloads (22.92\%).
\end{abstract}

Keywords: Bibliometrics, Research Productivity, IP Indian Journal of Library Science and Information Technology, Author Productivity, Collaboration Pattern.

\section{Introduction}

Journal is one of the most common scholarly communication publishing platform in present academics. Both print \& online journals published in a large number with a variety of coverage (scope), language and subject area. Now, according to Kevin et al. (2009), when a journal is studied bibliometrically, it displays a intuitive portrait of the journal that insight beyond superficial. Along with analyzing the quality, national \& international standing, degree of impact, research interest, structural description, and authorship \& collaboration pattern, a single journal studies provided a detailed multi-faceted picture of the characteristics of that journal (Nebelong-Bonnevie \& Faber Frandsen, 2006). Professor Tiew, (1997) was the first to written a detailed review on single journal metrics studies concerning four categories viz. bibliometrics study, citation analysis, content analysis, and other aspects of bibliometrics study on single journals among over 102 literature. In the same context, the present study is an attempt to investigate the publication characteristics of the IP Indian Journal of Library Science and Information Technology using various bibliometric parameters.

\section{About Bibliometrics \\ Bibliometrics is a well-established discipline for a quantitative and statistical study of patterns of publication within a given subject field or body of literature. Bibliometric methods or "analysis" are now firmly established as scientific specialties and are an integral part of research evaluation methodology (Ellegaard \& Wallin, 2015). Bibliometrics is}

neither a new term nor a new area of research, and was supposed to be started with the Campbell (1896), who produced the first bibliometric study using statistical methods for studying subject scattering in publications. Later, Cole and Eale (1917) used the term Statistical Analysis to quantify the literature for their study on the history of comparative anatomy. However, the term bibliometrics was first coined by British Scientist Alan Pritchard (Prichard, 1969). Bibliometrics has now become the generic term for a whole range of specific measurements and indicators; its purpose is to measure the output of scientific and technological research through data derived from published literature.

\section{About the Source Journal}

The IP Indian Journal of Library Science and Information Technology (IJLSIT) (p-ISSN: 2582-1555, e-ISSN: 24569623) published by IP Innovative Publication Pvt. Ltd., under the Khyati Education and Research Foundation (KERF) ( $a$ non-profit society/registered under the society registration act, 1860). It is an open-access peer-reviewed journal, published half-yearly since 2006 but came into online mode on 22 February 2021. With the aim of faster and better dissemination of knowledge, the journal committed to publishing a research-oriented manuscript that addresses significant issues in all the subjects and areas of Library Science and Information Technology. The journal is indexed with or included in the following databases, viz. Index Copernicus, Google Scholar, Indian Science Abstracts, Academia.edu, National Science Library, J-gate, ROAD, CrossRef, and Microsoft Academic. (IP Innovative 
Publication Pvt. Ltd., 2021) The journal would allow free access (Open Access) to its contents licensed under a Creative Commons Attribution (CC BY 4.0), which increase the research interest (views, downloads \& citations) to the articles published in IJLSIT. Further, IJLSIT strictly follows library ethics \& only original article accepted and no types of plagiarism entertained. The publisher of IJLSIT provides plagiarism check software, Crossref Similarity Check (powered by iThenticate), to the editor and reviewers as a part of the manuscript submission system. (IP Innovative Publication Pvt. Ltd., n.d.)

\section{Literature Review}

Naveed et al. (2021) analysed the present status of the Library Quarterly (LQ) and explored the published documents between 2010-2019. Bibliometric data collected through Web of Science Core Collection and VOSviewer, Biblioshiny, MSExcel, etc. tools used for bibliometric analysis. The study evaluates that a total (469) documents published in this timespan in LQ. Ratten et al. (2020) aimed to analyse the growth and change of the Thunderbird International Business Review. A bibliometric analysis was conducted with a specific focus on the past 15-year time period and the most cited articles, authors, and countries were stated. In addition, the topics covered were discussed, which shows the journal shifting from a broad reliance on international business topics to diversifying into more interdisciplinary topic areas. Zurita et al. (2020) performed a bibliometric analysis of the Journal of Network and Computer Applications for 1997-2019. The data was collected from the Clarivate Analytics Web of Science database, and the research began with the creation of a publication and citation structure. Later, the leading authors, institutions, and countries were introduced and VOSviewer software was able to analyse co-citations, bibliographic coupling, and keyword co-occurrence. La Paz et al. (2019) presented an overview of the leading research trends in the papers that the Information Systems Journal has published during 1991-2015 via a bibliometric and ontological analysis. The publication and citation analysis considered from the bibliometric perspective and bibliographic coupling \& cocitation analysis development for geographical analysis of the bibliographic material. Gaviria-Marin et al. (2018) aimed to show an updated analysis of their publications to provide a general overview of the Journal of Knowledge Management, focusing on a bibliometric analysis of its publications between 1997 and 2016. The performance analysis used a series of bibliometric indicators such as hindex, productivity and citations, and considered different dimensions, including papers, authors, universities and countries. VOSviewer software is used to carry out the mapping of the science of JKM, which, based on the concurrence of keywords and co-citation points of view. Sahoo et al. (2017) examined the articles published in the Electronic Journal of Knowledge Management during the period from 2003-2013. With the help of bibliometric methods, the study identified the publication output, authorship pattern, degree of collaboration, most prolific contributors, the geographical distribution of papers, referencing pattern, self-citation pattern and several other characteristics. The study findings revealed that 2009 was the most productive year, research papers are given the most importance, the majority of the papers are multi-authored, the UK contributed most as a country and the degree of collaboration is found to be 0.70. Ali et al. (2015) bibliometrically analysed the published articles \& their characteristics of the Journal of Academic Librarianship during 1999-2014. The findings of the study suggested that the majority of the documents published in 1999, USA covered the majority of the publications (1498 or $80.84 \%$ ), $76(3.60 \%)$ publications come from the University of Houston, keyword "Academic libraries" account for the highest numbers of articles (30), single-authored collaborate in a larger extent than multiple authors and degree of collaboration is 0.27 . Shanmugam (2011) dealt with the bibliometric analysis of articles and references contributed in the Indian Journal of Chemistry during 2005-2009. The analysis covered the number of articles, authorship pattern, forms of the document cited, authorship patterns, preferred cited journals, and thus discussed the overall merits \& weakness of the journal.

\section{Study Objectives}

The major objectives of the present study are:

1. To ascertain year wise and volume wise number of articles.

2. To examine the authorship pattern $\&$ degree of collaboration.

3. To know the state wise contribution of the articles.

4. To identify the most productive authors of the journal.

5. To ascertain the average length of the articles.

6. To discover the average types of materials used in writing the articles.

7. To display the number of references per article.

8. To highlight the trends of research based on the articles published in the journal.

\section{Research Methodology}

The research problem investigated by the study was the culmination of various significant parameters of the articles published in IJLSIT. All the articles of volumes 1-5 (20162020) was scanned manually and the data was stored in an ms-excel sheet for better visualization. Further, the obtained data were tabulated and analyzed as per the objectives of the study. Protocols discussed within the article addressed essential interrelated parameters that incorporated: year-wise analysis of papers and distribution, authorship pattern, ranking of contributing authors, research collaboration, geographical contribution, article length, reference count, cited source types, research type, research trend, and research interests. 


\section{Results \& Discussion}

\section{Volume \& Issue Wise Distribution of Articles}

Table 1 depicts the year- or volume-wise trend of research output of the IJLSIT throughout the period 2016 to 2020. A total of 101 articles were published in these five volumes and a maximum number of articles viz. 26 (25.74\%) were published in the year 2019 (Vol. 4). It is followed by $2017 \&$ 2018 with $22(21.78 \%)$ articles in each of the $2^{\text {nd }} \& 3^{\text {rd }}$ volume. Although, the year 2016 (vol. 1) with 12 (11.88\%) articles is the least productive year.

Table 1: Year or Volume Wise Research Output of IJLSIT

\begin{tabular}{|c|c|c|c|c|c|}
\hline Year & Volume & Issue & No of Article & Total & Percentage \\
\hline \multirow[t]{2}{*}{2016} & \multirow[t]{2}{*}{1} & 1 & 4 & \multirow[t]{2}{*}{12} & \multirow[t]{2}{*}{11.88} \\
\hline & & 2 & 8 & & \\
\hline \multirow[t]{2}{*}{2017} & \multirow[t]{2}{*}{2} & 1 & 8 & \multirow[t]{2}{*}{22} & \multirow[t]{2}{*}{21.78} \\
\hline & & 2 & 14 & & \\
\hline \multirow[t]{2}{*}{2018} & \multirow[t]{2}{*}{3} & 1 & 14 & \multirow[t]{2}{*}{22} & \multirow[t]{2}{*}{21.78} \\
\hline & & 2 & 8 & & \\
\hline \multirow[t]{2}{*}{2019} & \multirow[t]{2}{*}{4} & 1 & 10 & \multirow[t]{2}{*}{26} & \multirow[t]{2}{*}{25.74} \\
\hline & & 2 & 16 & & \\
\hline \multirow[t]{2}{*}{2020} & \multirow[t]{2}{*}{5} & 1 & 11 & \multirow[t]{2}{*}{19} & \multirow[t]{2}{*}{18.81} \\
\hline & & 2 & 8 & & \\
\hline \multicolumn{4}{|c|}{ All Total } & 101 & 100.00 \\
\hline
\end{tabular}

\section{Authorship \& Collaboration Patterns}

Following Table 2 displays the detailed authorship patterns of the articles published in these five volumes during 2016-2020. Out of the 101 articles, $53.47 \%$ (or 54) articles contributed by a single author, followed by $32(31.68 \%$ ) contributed by two authors and the rest of the $15(14.85 \%)$ contributed by three or more authors. In all of IJLSIT's volumes (1-6), the contribution of a total of 6 authors in a single article (volume 5 , issue 2) is the maximum.

Table 2: Authorship Pattern of IJLSIT Research Output

\begin{tabular}{|c|c|c|c|c|c|c|c|c|}
\hline \multirow{3}{*}{$\frac{\text { Year }}{2016}$} & \multirow{2}{*}{$\begin{array}{c}\text { Volume } \\
1\end{array}$} & Issue & \multicolumn{2}{|c|}{ Single Author } & \multicolumn{2}{|c|}{ Double Author } & \multicolumn{2}{|c|}{ More than two author } \\
\hline & & 1 & 2 & \multirow[t]{2}{*}{5} & 1 & \multirow[t]{2}{*}{6} & 1 & \multirow[t]{2}{*}{1} \\
\hline & & 2 & 3 & & 5 & & 0 & \\
\hline \multirow[t]{2}{*}{2017} & \multirow[t]{2}{*}{2} & 1 & 6 & \multirow[t]{2}{*}{14} & 1 & \multirow[t]{2}{*}{6} & 1 & \multirow[t]{2}{*}{2} \\
\hline & & 2 & 8 & & 5 & & 1 & \\
\hline \multirow[t]{2}{*}{2018} & \multirow[t]{2}{*}{3} & 1 & 7 & \multirow[t]{2}{*}{13} & 5 & \multirow[t]{2}{*}{7} & 2 & \multirow[t]{2}{*}{2} \\
\hline & & 2 & 6 & & 2 & & 0 & \\
\hline \multirow[t]{2}{*}{2019} & \multirow[t]{2}{*}{4} & 1 & 3 & \multirow[t]{2}{*}{11} & 5 & \multirow[t]{2}{*}{9} & 2 & \multirow[t]{2}{*}{6} \\
\hline & & 2 & 8 & & 4 & & 4 & \\
\hline \multirow[t]{2}{*}{2020} & \multirow[t]{2}{*}{5} & 1 & 5 & \multirow[t]{2}{*}{11} & 3 & \multirow[t]{2}{*}{4} & 3 & \multirow[t]{2}{*}{4} \\
\hline & & 2 & 6 & & 1 & & 1 & \\
\hline \multicolumn{3}{|c|}{ All Total (101) } & \multicolumn{2}{|c|}{54} & \multicolumn{2}{|c|}{32} & \multicolumn{2}{|c|}{15} \\
\hline \multicolumn{3}{|c|}{ Percentage (100.00) } & \multicolumn{2}{|c|}{$\mathbf{5 3 . 4 7}$} & \multicolumn{2}{|c|}{31.68} & \multicolumn{2}{|c|}{14.85} \\
\hline
\end{tabular}

The 'Degree of Collaboration' is known as the ratio of the number of collaborative research papers to the total number of research papers in the discipline during a certain period of time (Subramanyam, 1983) and can be written as ,

$$
\mathrm{DC}=\frac{\mathrm{N}_{\mathrm{m}}}{\mathrm{N}_{\mathrm{m}}+\mathrm{N}_{\mathrm{s}}}
$$

Where,

$\mathrm{DC}=$ degree of collaboration

$\mathrm{N}_{\mathrm{m}}=$ number of multiple-authored articles

$\mathrm{N}_{\mathrm{s}}=$ number of single authored research articles.

Table 3 depicts the volume- or year-wise degree of collaboration among the authors. It is seen from the table 3 that it ranges from 0.36 to 0.58 . However, maximum collaboration is seen in $2016 \& 2019$ (viz. 0.58) and minimum in the year 2017 (viz. 0.36). In these five years, the overall collaboration rate is 0.47 , which is a little less than half of the total published article in IJLSIT. 
Table 3: Degree of Collaboration

\begin{tabular}{|c|c|c|c|c|c|}
\hline Year & Volume & $\begin{array}{c}\text { Single } \\
\text { Author }\end{array}$ & $\begin{array}{c}\text { Multiple } \\
\text { Author }\end{array}$ & Total & $\begin{array}{c}\text { Degree of } \\
\text { Collaboration }\end{array}$ \\
\hline 2016 & 1 & 5 & 7 & 12 & 0.58 \\
\hline 2017 & 2 & 14 & 8 & 22 & 0.36 \\
\hline 2018 & 3 & 13 & 9 & 22 & 0.41 \\
\hline 2019 & 4 & 11 & 15 & 26 & 0.58 \\
\hline 2020 & 5 & 11 & 8 & 19 & 0.42 \\
\hline \multicolumn{2}{|c|}{ Total } & $\mathbf{5 4}$ & $\mathbf{4 7}$ & $\mathbf{1 0 1}$ & $\mathbf{0 . 4 7}$ \\
\hline
\end{tabular}

\section{Most Productive Authors}

It is identified from the study that 120 authors contributed to all of 101 articles in IJLSIT (vol. 1-5). There were 11 contributions from two authors, 9 from three authors, 5 from four or more authors, and the rest from single authors. Table 4 shows the rank wise most productive authors identified during 2016 - 2020. It is clear from the table that Hemantha Kumar G.H. is the most productive author with 9 publications, followed by Elijah Ojowu ODE and Dakshata Avinash Dukare with 6 \& 5 publications, respectively. While ranking between authors with equal number of publication, the position of the author (first, second or more) taken under consideration.

Table 4: Most Productive Authors of IJLSIT

\begin{tabular}{|c|l|c|c|c|c|}
\hline Rank & Author & 1st Author & 2nd Author & $\begin{array}{c}\text { 3rd \& More } \\
\text { Author }\end{array}$ & No of Paper \\
\hline 1 & Hemantha Kumar G.H. & 5 & 4 & 0 & 9 \\
\hline 2 & Elijah Ojowu ODE & 6 & 0 & 0 & 6 \\
\hline 3 & Dakshata Avinash Dukare & 4 & 1 & 0 & 5 \\
\hline 4 & Rajeev Manhas & 3 & 1 & 0 & 4 \\
\hline 4 & Suvarna S. Hiremath & 3 & 1 & 0 & 4 \\
\hline 5 & Arunadevi S Lingam & 3 & 0 & 0 & 3 \\
\hline 5 & S. L. Jadhav & 3 & 0 & 0 & 3 \\
\hline 6 & Mohammad Asif & 2 & 1 & 0 & 3 \\
\hline 7 & K. K. Singh & 1 & 2 & 0 & 3 \\
\hline 7 & Shinderpal Kaur & 1 & 2 & 0 & 3 \\
\hline 7 & Somvir & 1 & 2 & 0 & 3 \\
\hline 8 & Rajesh Kathane & 1 & 1 & 1 & 3 \\
\hline 8 & Shivakumar Acharya & 0 & 1 & 1 & 3 \\
\hline 9 & Somashekar Lalasangi & 2 & 0 & 0 & 3 \\
\hline 10 & Jagdish Narharrao Kulkarni & 2 & 0 & 0 & 2 \\
\hline 10 & Lalita Honhaga & 2 & 0 & 0 & 2 \\
\hline 10 & Manzoor Babu V & 2 & 0 & 0 & 2 \\
\hline 10 & P. Anuradha & 2 & 0 & 0 & 2 \\
\hline 10 & Pushp Lata & 2 & 0 & 0 & 2 \\
\hline 10 & Rajnish Trivedi & 2 & 0 & 0 & 2 \\
\hline 10 & Subhash Chand & 2 & 0 & 0 & 2 \\
\hline 10 & Sudhakara S & 2 & 0 & 0 & 2 \\
\hline 10 & Yogita Sharma & 0 & 1 & 1 & 2 \\
\hline 11 & P. Nageswara Rao & 0 & 1 & 1 & 2 \\
\hline 11 & Vijayalaxmi Sunagar & & & & \\
\hline & & & 1 & 0 & 2 \\
\hline
\end{tabular}

\section{Contributor's Origin}

The following figure 1 depicts the origin of the contributors of IJLST. It can be easily identified that among 101 articles of IJLSIT (vol. 1-5), 90\% (viz. 91) contributed by authors of Indian origin, whereas, rest of the $10(10 \%)$ contributed by authors from other countries, specifically from different parts of Africa. It is also important to note that no such article identified that collaboratively contributed by Indian \& Foreign authors. 


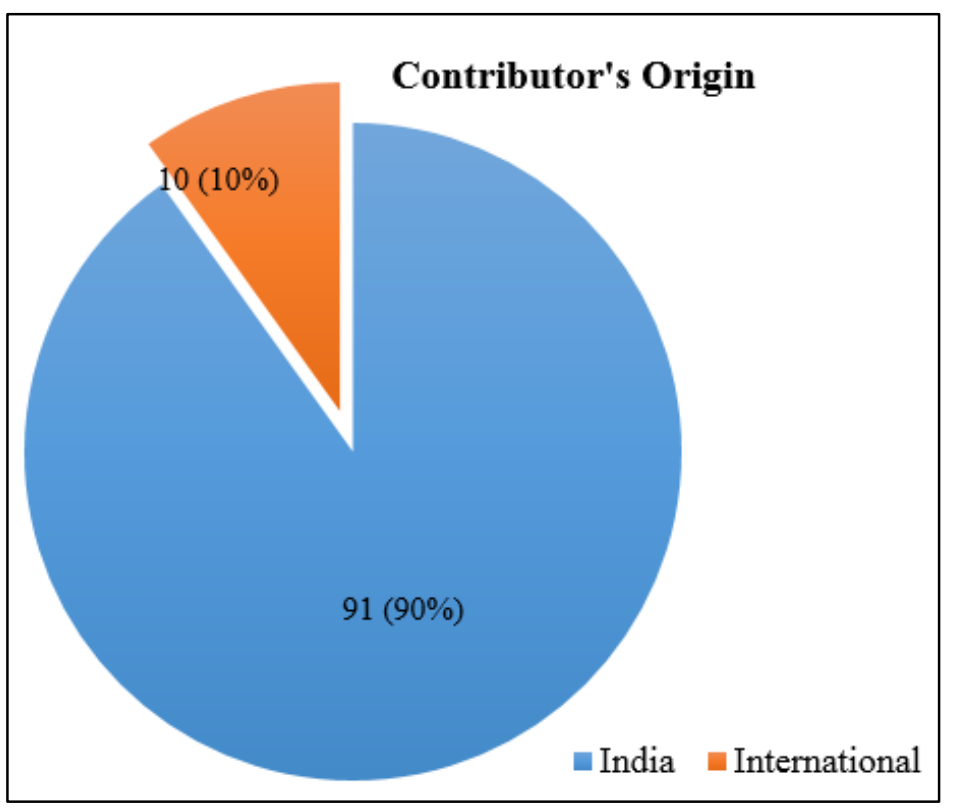

Fig. 1: Origin of the IJLST Contributors

\section{State Wise Contributions:}

State-wise contribution denotes the nationwide acceptance of the journal. From table 5 it can be identified that among the 91 contributions from Indian authors, the state Maharastra covers a maximum of $18.81 \%$ (19), followed by Karnataka \& Punjab with $12.87 \%$ (13) and $9.90 \%$ (10), respectively. On the other side, Rajasthan \& Odisha possess the least contribution with 1 $(0.99 \%)$ contribution each. States other than mentioned in the table has no contribution to IJLSIT between 2006-2020. It is important to note that, table 5 is structured with considering only the first author of each article published in IJLSIT.

Table 5: State wise Contribution to IJLSIT

\begin{tabular}{|c|l|c|c|}
\hline Rank & State & No of Contribution & Percentage \\
\hline 1 & Maharastra & 19 & 18.81 \\
\hline 2 & Karnataka & 13 & 12.87 \\
\hline 3 & Punjab & 10 & 9.90 \\
\hline 4 & Gujrat & 8 & 7.92 \\
\hline 5 & Andhra Pradesh & 7 & 6.93 \\
\hline 5 & Haryana & 7 & 6.93 \\
\hline 6 & Uttar Pradesh & 6 & 5.94 \\
\hline 7 & Madhya Pradesh & 5 & 4.95 \\
\hline 8 & Kerala & 4 & 3.96 \\
\hline 9 & J\&K & 3 & 2.97 \\
\hline 9 & Tamil Nadu & 3 & 2.97 \\
\hline 10 & Jharkhand & 2 & 1.98 \\
\hline 10 & Sikkim & 2 & 1.98 \\
\hline 11 & Rajasthan & 1 & 0.99 \\
\hline 11 & Odisha & 1 & 0.99 \\
\hline \multicolumn{2}{r|}{ International } & 10 & 9.90 \\
\hline & Total & $\mathbf{1 0 1}$ & $\mathbf{1 0 0 . 0 0}$ \\
\hline
\end{tabular}

\section{Affiliation wise Contribution:}

Table 6 indicates the affiliation wise contribution to the research output of IJLSIT during 2006-2020 (vol. 1-5). As directed in the table, Benue State University \& Rayalaseema University being the most contributed institutions with $4.95 \%$ (5) coverage each, followed by BLDE (Deemed to be University) \& Farook College, each with 3.96\% (4) coverage. Furthermore, there is a total of 8 institutions with $2.97 \%$ (3) and 6 institutions with $1.98 \%$ (2) coverage each. Rest 47 institutions have a single article contribution to IJLSIT. It is important to note that, table 6 is designed in such a way that only the first author of each published article of IJLSIT is considered. 
Table 6: Affiliation wise Contribution to IJLSIT

\begin{tabular}{|c|c|c|c|}
\hline Rank & Affiliation & No of Contribution & Percentage \\
\hline 1 & Benue State University & 5 & 4.95 \\
\hline 1 & Rayalaseema University & 5 & 4.95 \\
\hline 2 & BLDE (Deemed to be University) & 4 & 3.96 \\
\hline 2 & Farook College & 4 & 3.96 \\
\hline 3 & Baba Farid University of Health Sciences & 3 & 2.97 \\
\hline 3 & Ganga Institute of Technology and Management & 3 & 2.97 \\
\hline 3 & $\begin{array}{l}\text { Library and Information Centre, Indian Pharmacopoeia } \\
\text { Commission, Ministry of Health \& F.W., Govt. of India }\end{array}$ & 3 & 2.97 \\
\hline 3 & M. P. Birla Library \& Information Centre, Bombay Hospital Trust & 3 & 2.97 \\
\hline 3 & N. E. S. Science College, Nanded & 3 & 2.97 \\
\hline 3 & Oriental College of Pharmacy & 3 & 2.97 \\
\hline 3 & Punjab Agricultural University & 3 & 2.97 \\
\hline 3 & University of Kashmir & 3 & 2.97 \\
\hline 4 & All India Institute of Medical Sciences & 2 & 1.98 \\
\hline 4 & Duvvuru Ramanamma Women's (DRW) College & 2 & 1.98 \\
\hline 4 & Sardar Vallabhbhai Patel Institute of Technology & 2 & 1.98 \\
\hline 4 & Sikkim Manipal Institute of Medical Sciences & 2 & 1.98 \\
\hline 4 & Swami Ramanand Teerth Marathwada University & 2 & 1.98 \\
\hline 4 & University of Agricultural Sciences & 2 & 1.98 \\
\hline \multirow{2}{*}{\multicolumn{2}{|c|}{$\begin{array}{c}\text { Other (Single article contributors) } \\
\text { Total }\end{array}$}} & 47 & 46.53 \\
\hline & & 101 & 100.00 \\
\hline
\end{tabular}

\section{Designation wise Contribution:}

Table 7 displays the designation wise contribution to IJLSIT research output. Out of the 101 targeted sample article, 21 (20.79\%) covered by College Librarians. It is followed by University Librarians and Research Scholars with 11 (10.89\%) \& $10(9.90 \%)$ coverage each. Similar to table $5 \& 6$, table 7 also prepared by considering the only first author of each article into account.

Table 7: Designation wise Contribution to IJLSIT

\begin{tabular}{|c|l|c|c|}
\hline Rank & Designation & No of Contribution & Percentage \\
\hline 1 & College Librarian & 21 & 20.79 \\
\hline 2 & University Librarian & 11 & 10.89 \\
\hline 3 & Research Scholar & 10 & 9.90 \\
\hline 4 & Assistant Librarian & 9 & 8.91 \\
\hline 4 & Institutional Librarian & 9 & 8.91 \\
\hline 5 & Assistant Professor & 8 & 7.92 \\
\hline 6 & Lecturer & 7 & 6.93 \\
\hline 7 & Chief Librarian & 5 & 4.95 \\
\hline 7 & Junior Librarian & 5 & 4.95 \\
\hline 8 & Library Assistant & 3 & 2.97 \\
\hline & Other & 13 & 12.87 \\
\hline & Total & $\mathbf{1 0 1}$ & $\mathbf{1 0 0 . 0 0}$ \\
\hline
\end{tabular}

\section{Average Length of Articles}

Table 8 shows the length of articles categorised into four categories: 0-5, 6-10, 11-15, and 16-20 pages during 2016-2020 (vol $1-5)$. It is observed that the maximum number of articles viz, 65 out of $101(64.36 \%)$ published with $0-5$ pages of length. It is followed by, 6-10 pages with 30 (29.70) coverage, 11-15 pages with $4(3.96 \%)$ coverage and 16-20 pages with 2 (1.98\%) coverage. It is also important to note that there is no article in IJLSIT (vol. 1-5) that contains more than 20 pages.

Table 8: Average Length of Articles in IJLSIT

\begin{tabular}{|c|c|c|c|c|c|c|c|}
\hline Page Range & $\mathbf{2 0 1 6}$ & $\mathbf{2 0 1 7}$ & $\mathbf{2 0 1 8}$ & $\mathbf{2 0 1 9}$ & $\mathbf{2 0 2 0}$ & Total & Percentage \\
\hline $\mathbf{0 - 5}$ & 7 & 9 & 16 & 19 & 14 & 65 & 64.36 \\
\hline $\mathbf{6 - 1 0}$ & 5 & 8 & 6 & 6 & 5 & 30 & 29.70 \\
\hline
\end{tabular}




\begin{tabular}{|c|l|l|l|l|l|l|l|}
\hline $\mathbf{1 1 - 1 5}$ & 0 & 3 & 0 & 1 & 0 & 4 & 3.96 \\
\hline 16-20 & 0 & 2 & 0 & 0 & 0 & 2 & 1.98 \\
\hline More than 20 & 0 & 0 & 0 & 0 & 0 & 0 & 0.00 \\
\hline
\end{tabular}

\section{Use of References per Article}

Table 9 depicts the number of references used in published articles in the last five-year volumes of IJLSIT (vol. 1-5). It is very clear from the table that the maximum number of articles (35 or 34.65\%) in IJLSIT consist of 6-10 references per article; followed by 22 articles $(21.78 \%)$ with $0-5$ references and 20 articles (19.80\%) with 11-15 references. It is important to note that, two articles consist of more than 50, viz. $57 \& 55$ references.

Table 9: Use of References per Article

\begin{tabular}{|c|c|c|c|c|c|c|c|}
\hline Reference Count & $\mathbf{2 0 1 6}$ & $\mathbf{2 0 1 7}$ & $\mathbf{2 0 1 8}$ & $\mathbf{2 0 1 9}$ & $\mathbf{2 0 2 0}$ & Total & Percentage \\
\hline $\mathbf{0 - 5}$ & 3 & 5 & 4 & 7 & 3 & 22 & 21.78 \\
\hline $\mathbf{6 - 1 0}$ & 3 & 6 & 10 & 7 & 9 & 35 & 34.65 \\
\hline $\mathbf{1 1 - 1 5}$ & 4 & 4 & 3 & 6 & 3 & 20 & 19.80 \\
\hline $\mathbf{1 6 - 2 0}$ & 2 & 3 & 2 & 4 & 2 & 13 & 12.87 \\
\hline More than 20 & 0 & 4 & 3 & 2 & 2 & 11 & 10.89 \\
\hline
\end{tabular}

\section{Types of Materials Cited in the Articles}

Table 10 presents the type of material used by authors while constructing their articles as a reference or background study. From the table, it can be identified that periodical articles are the most used references with more than half coverage percentage viz. $55.41 \%$ (or 671). It is followed by, online article and Book/Book Chapter with $18.74 \%$ (227) \& 13.46\% (163) coverage respectively. If the year- or volume-wise distribution considered, 2017 (vol. 2) comprising a maximum number of references (345 or $28.49 \%$ ), while 2016 (vol. 1) minimum among all (117 or $9.66 \%$ ).

Table 10: Types of Materials Cited in the Articles of IJLSIT

\begin{tabular}{|l|c|c|c|c|c|c|c|}
\hline Type of Materials Cited & $\begin{array}{c}\mathbf{2 0 1 6} \\
\text { (vol. 1) }\end{array}$ & $\begin{array}{c}\mathbf{2 0 1 7} \\
\text { (vol. 2) }\end{array}$ & $\begin{array}{c}\mathbf{2 0 1 8} \\
\text { (vol. 3) }\end{array}$ & $\begin{array}{c}\mathbf{2 0 1 9} \\
\text { (vol. 4) }\end{array}$ & $\begin{array}{c}\mathbf{2 0 2 0} \\
\text { (vol. 5) }\end{array}$ & Total & Percentage \\
\hline Periodical Article & 69 & 220 & 121 & 135 & 126 & 671 & 55.41 \\
\hline Book/Book Chapter & 12 & 41 & 56 & 39 & 15 & 163 & 13.46 \\
\hline Conference Papers & 4 & 19 & 18 & 27 & 11 & 79 & 6.52 \\
\hline Online Material & 28 & 51 & 40 & 62 & 46 & 227 & 18.74 \\
\hline Thesis/Dissertations & 0 & 3 & 0 & 0 & 5 & 8 & 0.66 \\
\hline Manual/Handbook & 2 & 10 & 6 & 1 & 2 & 21 & 1.73 \\
\hline Manuscript & 1 & 1 & 6 & 4 & 2 & 14 & 1.16 \\
\hline Dictionary/Encyclopedia & 0 & 0 & 2 & 1 & 10 & 13 & 1.07 \\
\hline Others & 1 & 0 & 8 & 4 & 2 & 15 & 1.24 \\
\hline Total & 117 & 345 & 257 & 273 & 219 & 1211 & 100.00 \\
\hline Percentage & 9.66 & 28.49 & 21.22 & 22.54 & 18.08 & 100.00 & - \\
\hline
\end{tabular}

\section{Research Publication Types}

Table 11 shows the categories of research published in IJLSIT during 2016-2020 (vol. 1- 5). With coverage of 72.28\% (73), original research articles are the most common publications in IJLSIT; comprising Review Article with 20.79\% (21) and Case Report with 4.95\% (5) coverage. There are also two (2) Other types of articles that don't meet the criteria of any of the previously mentioned categories.

Table 11: Research Publication Categories in IJLSIT

\begin{tabular}{|c|c|c|c|c|c|c|}
\hline Year & Volume & Issue & $\begin{array}{c}\text { Original } \\
\text { Article }\end{array}$ & $\begin{array}{c}\text { Review } \\
\text { Article }\end{array}$ & $\begin{array}{c}\text { Case } \\
\text { Report }\end{array}$ & Others \\
\hline 2016 & \multirow{2}{*}{1} & 1 & 1 & 2 & 1 & 0 \\
\cline { 2 - 7 } & 2 & 2 & 8 & 0 & 0 & 0 \\
\hline 2017 & 2 & 1 & 6 & 2 & 0 & 0 \\
\hline \multirow{2}{*}{2018} & \multirow{2}{*}{3} & 2 & 9 & 4 & 0 & 1 \\
\cline { 2 - 7 } & & 2 & 8 & 2 & 3 & 0 \\
\hline
\end{tabular}




\begin{tabular}{|c|c|c|c|c|c|c|}
\hline 2019 & \multirow{2}{*}{4} & 1 & 7 & 2 & 1 & 0 \\
\cline { 3 - 7 } & & 2 & 9 & 7 & 0 & 0 \\
\hline \multirow{2}{*}{2020} & 5 & 1 & 9 & 2 & 0 & 0 \\
\cline { 3 - 7 } & & 2 & 7 & 0 & 0 & 1 \\
\hline \multicolumn{2}{|c|}{ All Total (101) } & 73 & 21 & 5 & 2 \\
\hline \multicolumn{2}{|c|}{ Percentage (100.00) } & 72.28 & 20.79 & 4.95 & 1.98 \\
\hline
\end{tabular}

\section{Research Trends}

To discover common research patterns in the published articles in IJLSIT, each paper was first thoroughly reviewed before being classified into ten major categories, as shown in Table 12. Among the 101 published articles in IJLSIT (vol. 1-5), a maximum of 19 articles (18.81\%) related to the field Digital Library, closely followed by Information Seeking Behaviour, Information Services and Information Communication Technology with 17 (16.83\%), 15 (14.85\%) \& 14 (13.86\%) articles respectively. Again, among all of the category the Research Methods \& Copyright, Plagiarism \& Library Ethics field have the least coverage (viz. 2 articles each).

Table 12: Research Trends of the Published Articles in IJLSIT

\begin{tabular}{|l|c|c|c|c|c|c|c|}
\hline Research Areas & $\mathbf{2 0 1 6}$ & $\mathbf{2 0 1 7}$ & $\mathbf{2 0 1 8}$ & $\mathbf{2 0 1 9}$ & $\mathbf{2 0 2 0}$ & Total & Percentage \\
\hline Information Communication Technology & 2 & 1 & 3 & 4 & 4 & 14 & 13.86 \\
\hline Metrics Studies & 1 & 1 & 2 & 0 & 1 & 5 & 4.95 \\
\hline Library Management & 0 & 1 & 4 & 3 & 4 & 12 & 11.88 \\
\hline Digital Library & 2 & 3 & 4 & 6 & 4 & 19 & 18.81 \\
\hline Information Services & 3 & 2 & 3 & 6 & 1 & 15 & 14.85 \\
\hline Research Methods & 0 & 2 & 0 & 0 & 0 & 2 & 1.98 \\
\hline Preservation \& Conservation & 1 & 1 & 2 & 1 & 2 & 7 & 6.93 \\
\hline Information Seeking Behaviour & 3 & 7 & 4 & 1 & 2 & 17 & 16.83 \\
\hline Copyright, Plagiarism \& Library Ethics & 0 & 0 & 0 & 2 & 0 & 2 & 1.98 \\
\hline Miscellaneous & 0 & 4 & 0 & 3 & 1 & 8 & 7.92 \\
\hline
\end{tabular}

\section{Research Interest}

Research interest denotes the acceptability \& importance of published research to fellow researchers. It can be determined by various kinds of usage statistics, e.g. by citation analysis, by recommendation, by views \& downloads count etc. In this study, the views \& downloads stats of the published articles considered to determine the research interest of a particular article. Among the 101 published articles in IJLSIT, the article "E-learning, e-searching and e-resource management in the libraries" by Mohammad Asif \& K. K. Singh have the highest views (1829) and downloads (985) record. Again, the year 2018, vol. 3, issue 1 consists of the maximum views number (14663 or $18.01 \%$ ) and the year 2020 , vol. 5 , issue 1 has the most number of downloads (9279 or $22.92 \%)$.

Table 13: Research Interests of the Published Articles in IJLSIT

\begin{tabular}{|c|c|c|c|c|}
\hline Year & Volume & Issue & View* & Download* \\
\hline 2016 & 1 & 1 & 5057 & 1908 \\
& & & $(6.21 \%)$ & $(4.71 \%)$ \\
\cline { 3 - 5 } & & 2 & 8697 & 2813 \\
& & & $(10.68 \%)$ & $(6.95 \%)$ \\
\hline 2017 & 2 & 1 & 6438 & 2061 \\
& & & $(7.91 \%)$ & $(5.09 \%)$ \\
\cline { 3 - 5 } & & 2 & 11605 & 3682 \\
& \multirow{2}{*}{2018} & & $(14.26 \%)$ & $(9.10 \%)$ \\
& & & 14663 & 6732 \\
& & 2 & $(18.01 \%)$ & $(16.63 \%)$ \\
\hline \multirow{2}{*}{2019} & 4 & 1 & $(8.84 \%)$ & $(6.95 \%)$ \\
& & & 9446 & 3883 \\
& & & $(11.60 \%)$ & $(9.59 \%)$ \\
\cline { 3 - 5 } & & 2 & 12006 & 5938 \\
& & & $(14.75 \%)$ & $(14.67 \%)$ \\
\hline
\end{tabular}




\begin{tabular}{|c|c|c|c|c|}
\hline 2020 & 5 & 1 & 4683 & 9279 \\
& & & $(5.75 \%)$ & $(22.92 \%)$ \\
\cline { 3 - 5 } & & 2 & 1608 & 1373 \\
& & & $(1.98 \%)$ & $(3.39 \%)$ \\
\hline \multicolumn{3}{|c|}{ All Total } & $\mathbf{8 1 4 0 2}$ & $\mathbf{4 0 4 8 2}$ \\
& & $(\mathbf{1 0 0 . 0 0 \% )}$ & $\mathbf{( 1 0 0 . 0 0 \% )}$ \\
\hline
\end{tabular}

(*denotes that the data of total "View" and "Download" collected on 8 June 2021)

\section{Major Findings of the Study}

The major findings of the study consists of the following points,

1. In the case of year- or volume-wise trend of research output of the IJLSIT a maximum number of articles viz. $26(25.74 \%)$ were published in the year 2019 (vol. 4), followed by $2017 \& 2018$ with $22(21.78 \%)$ articles in each of the $2^{\text {nd }} \& 3^{\text {rd }}$ volume.

2. In IJLSIT, $53.47 \%$ (or 54) articles contributed by a single author, followed by $32(31.68 \%)$ contributed by two authors and the rest of the $15(14.85 \%)$ contributed by three or more authors.

3. Articles in IJLSIT possess overall collaboration rate is 0.47 , where the maximum collaboration is seen in 2016 \& 2019 (viz. 0.58) and minimum in the year 2017 (viz. $0.36)$.

4. In this five-year period, viz. 2016-2020, Hemantha Kumar G.H. is the most productive author in IJLSIT with 9 publications, followed by Elijah Ojowu ODE and Dakshata Avinash Dukare with $6 \& 5$ publications, respectively.

5. Among 101 articles of IJLSIT (vol. 1-5), 90\% (viz. 91) contributed by Indian authors, and the rest of the 10 (10\%) by foreign authors.

6. Among the 91 contributions from Indian authors, Maharastra covers a maximum of $18.81 \%$ (19), followed by Karnataka \& Punjab with $12.87 \%$ (13) and $9.90 \%$ (10), respectively.

7. Benue State University \& Rayalaseema University being the most contributed institutions with $4.95 \%$ (5) coverage each, followed by BLDE (Deemed to be University) \& Farook College, each with $3.96 \%$ (4) coverage.

8. Among the different designation types, 21 (20.79\%) covered by College Librarians, followed by University Librarians and Research Scholars with 11 (10.89\%) \& $10(9.90 \%)$ coverage each.

9. Out of the 101 published articles, $65(64.36 \%)$ published with $0-5$ pages of length, followed by 6-10 pages with 30 (29.70) coverage, $11-15$ pages with $4(3.96 \%)$ coverage and $16-20$ pages with $2(1.98 \%)$ coverage.

10. The maximum number of articles (35 or $34.65 \%$ ) in IJLSIT consist of 6-10 references per article; followed by 22 articles $(21.78 \%)$ with $0-5$ references and 20 articles (19.80\%) with 11-15 references.

11. The periodical articles are the most used references with $55.41 \%$ (or 671) coverage, followed by online article and Book/Book Chapter with $18.74 \%$ (227) \& $13.46 \%$ (163) coverage respectively.
12. Among the research types, Original research articles is the most common (72.28\% or 73) is IJLSIT, comprising Review Article with $20.79 \%$ (21) and Case Report with $4.95 \%$ (5) coverage.

13. A maximum of 19 articles $(18.81 \%)$ related to the field Digital Library, closely followed by Information Seeking Behaviour, Information Services and Information Communication Technology with 17 (16.83\%), $15 \quad(14.85 \%) \quad \& \quad 14 \quad(13.86 \%)$ articles respectively.

14. The article "E-learning, e-searching and e-resource management in the libraries" by Mohammad Asif \& K. K. Singh have the highest views (1829) and downloads (985) record in IJLSIT (vol. 1-5).

15. Similarly, the year 2018 , vol. 3 , issue 1 consists of the maximum views number (14663 or $18.01 \%$ ) and the year 2020 , vol. 5 , issue 1 has the most number of downloads (9279 or $22.92 \%)$.

\section{Conclusion}

Bibliographic analysis of a journal is meant to explore the impact of the journal on the academic community and as well as immediate society. The IP Indian Journal of Library Science and Information Technology does not have a long history but it has covered a wide range of topics in Library Science and Information Technology throughout the last five years (2016-2020). Authors from various parts of India contributed to the journal with their unique research ideas and the journal rich with some foreign contribution also. Several significant aspects of modern age Library Science education are studied in the journal. It is easy to assume from the affiliation and designation of the contributors (authors) that authors from various positions and institutional backgrounds selected this publication as a legitimate source for publishing their research. While the last two years views \& downloads record also indicates the increasing usage of this journal. Last but not least, IJLSIT supports the spirit and philosophy of Open Access which is in sync with FAIFE owing to its visible role in sharing intellectual freedom for building information democracy.

\section{Conflict of Interest}

The authors declare that there are no conflicts of interest in this paper.

\section{Source of Funding}

None. 


\section{References}

1. Kevin WUA, A.n, Z., \& N.b, A. (2009). Bibliometric Studies On Single Journals: A Review. Malaysian J Libr Inf Sci. 2009;14(1):17-55.

https://mjlis.um.edu.my/index.php/MJLIS/article/view/6951

2. Nebelong-Bonnevie E, Faber FT. Journal citation identity and journal citation image: a portrait of the Journal of

Documentation. J Documentation. 2006;62(1):30-57. https://doi.org/10.1108/00220410610642039

3. Tiew WS. Single Journal Bibliometric Studies: A Review. Malaysian J Libr Inf Sci. 1997;2(2):93-114. https://mjlis.um.edu.my/index.php/MJLIS/article/view/6634

4. Ellegaard O, Wallin JA. (2015). The bibliometric analysis of scholarly production: How great is the impact?.

Scientometrics. 2015;105(3):1809-31. https://doi.org/10.1007/s11192-015-1645-Z

5. Campbell FBF. The Theory of the National and International Bibliography: with Special Reference to the Introduction of System in the Record of Modern Literature. Library Bureau, London (England). 1896

6. Cole FJ, Eales NB. The History of Comparative Anatomy. Sci Progress. 1917;11:578-96.

7. Prichard A. Statistical Bibliography or Bibliometrics. J Libr Documentation. 1969;25(1):348-49.

8. IP Innovative Publication Pvt. Ltd. IJLSIT-IP Indian Jf Libr Sci Inf Technol. 2021. About Us.

https://www.ipinnovative.com/journals/IJLSIT/about-us

9. IP Innovative Publication Pvt. Ltd. (n.d.). Plagiarism IP Innovative Publication Pvt. Ltd. Retrieved June 8, 2021, from https://www.ipinnovative.com/guidelines/author/plagiarism/8

10. Naveed M, Ali N, Aslam S, Siddique N. Research Output of The Library Quarterly: A Bibliometric Analysis during 20102019. Library Philosophy and Practice (E-Journal). 2021. https://digitalcommons.unl.edu/libphilprac/5377

11. Ratten V, Pellegrini MM, Fakhar MM, Dabić M. Trends and changes in Thunderbird International Business Review journal: A bibliometric review. Thunderbird Int Business Rev. 2020;62(2);1-12. https://doi.org/10.1002/tie.22124

12. Zurita G, Shukla AK, Pino JA, Merigó JM, Lobos-Ossandón $\mathrm{V}$, Muhuri PK et al. A bibliometric overview of the Journal of Network and Computer Applications between 1997 and 2019. J Network Computer Appl. 2020;165:102695. https://doi.org/10.1016/j.jnca.2020.102695

13. La Paz A, Merigó JM, Powell, P., Ramaprasad, A., \& Syn, T. (2019). Twenty-five years of the Information Systems Journal: A bibliometric and ontological overview. Information Systems Journal, 30(3), 431-457. https://doi.org/10.1111/isj.12260

14. Gaviria-Marin, M., Merigo JM, Popa S. Twenty years of the Journal of Knowledge Management: a bibliometric analysis. $J$ Knowledge Manag. 2018;22(8):1655-87. https://doi.org/10.1108/jkm-10-2017-0497

15. Sahoo J, Meher G, Mohanty B. Electronic Journal of Knowledge Management: A Bibliometric Analysis. Libr Philos Pract (E-J). 2017. https://digitalcommons.unl.edu/libphilprac/1638

16. Ali H. A Bibliometric Analysis of the Journal of Academic Librarianship. Int J Libr Inf Stud. 2015;5(4):83-90. https://www.ijlis.org/abstract/a-bibliometric-analysis-of-thejournal-of-academic-librarianship-69773.html

17. Shanmugam, T. Bibliometric Analysis of the Indian Journal of Chemistry. Libr Philos Pract (E-J). 2011. https://www.researchgate.net/publication/234144758

18. Subramanyam K. Bibliometric Studies of Research Collaboration: A Review. J Inf Sci. 1983;6(1):33-8.

How to cite: Panda S. Analysis of published research in IP Indian Journal of Library Science and Information Technology: A Bibliometric Study during 2016-2020. IP Indian J Libr Sci Inf Technol. 2021;6(1):20-9. 